Zeszyty Naukowe Szkoły Głównej Gospodarstwa Wiejskiego w Warszawie

Problemy Rolnictwa Światowego tom 18 (XXXIII), zeszyt 4, 2018: 304-312

DOI: 10.22630/PRS.2018.18.4.120

Wiesława Kuźniar $^{1}$, Marta Kawa ${ }^{2}$

Uniwersytet Rzeszowski

\title{
Konsumenci wobec regionalnych produktów tradycyjnych w kontekście ogólnoświatowych zmian w zachowaniach konsumentów na rynku żywności
}

\section{Consumer Attitudes Towards Regional Traditional Products in the Context of Global Changes in Consumer Behaviour on Food Market}

\begin{abstract}
Synopsis. Zmiany w postawach i zachowaniach konsumentów znajdują odzwierciedlenie w dynamicznym rozwoju określonych kategorii produktów, wśród których ważną rolę odgrywają produkty tradycyjne, postrzegane przez nabywców jako zdrowe, smaczne, nawiązujące do lokalnej tradycji kulinarnej. Bogata oferta takich produktów znajduje się w woj. podkarpackim, zajmującym pierwszą pozycję w Polsce pod względem liczby zrejestrowanych produktów. W opracowaniu w oparciu o wyniki badań ankietowych przeprowadzonych w 2018 r. na próbie $n=221$ wykazano, że bogata oferta produktów tradycyjnych regionu Podkarpacia cieszy się dużym zainteresowaniem konsumentów. W oparciu o wyniki testu Chi-kwadrat Pearsona można stwierdzić, że niezależnie od płci, wraz z wiekiem konsumentów zwiększa się zainteresowanie produktami tradycyjnymi, co znajduje odzwierciedlenie nie tylko w preferowaniu produktów tradycyjnych pochodzących z regionu, ale także w gotowości do zapłaty wyższej ceny w zamian na wysokie walory smakowe i zdrowotne tych produktów.
\end{abstract}

Słowa kluczowe: konsument, żywność, produkty tradycyjne

\begin{abstract}
The changes in consumer attitudes and behaviors are reflected in the dynamic development of specific product categories, among which traditional products play an important role, being perceived by buyers as healthy, tasty, as well as referring to local culinary tradition. A wide range of such products is available in the Podkarpackie province, which holds the first position in Poland in terms of the number of registered products. The study, based on the results of a survey conducted in 2018 on the $\mathrm{n}=221$ sample, showed that the rich offer of traditional products of the Podkarpacie region is very popular among consumers. Based on the results of the Chi-square Pearson test, it can be stated that regardless of gender, the interest of traditional products increases with the age of consumers, which is reflected not only in the preference for traditional products from the region, but also in readiness to pay a higher price in exchange for higher taste qualities and health values of these products.
\end{abstract}

Key words: consumers, food, traditional products

JEL Classification: D12, Q13, Q18

\footnotetext{
${ }^{1}$ dr hab. prof. UR, Katedra Marketingu i Przedsiębiorczości UR, ul. M. Ćwiklińskiej 2, 35-601 Rzeszów, e-mail: wkuzniar@ur.edu.pl; https://orcid.org/0000-0001-8562-3511

${ }^{2}$ dr, Katedra Marketingu i Przedsiębiorczości UR, ul. M. Ćwiklińskiej 2, 35-601 Rzeszów, e-mail: marka@ur.edu.pl; https://orcid.org/0000-0002-3023-9085
} 


\section{Wprowadzenie}

Konsumenci XXI wieku stają się coraz bardziej świadomi i uwrażliwieni na jakość zakupywanej oraz spożywanej przez nich żywności. Z danych zawartych $\mathrm{w}$ Raporcie „Trendy na globalnym rynku żywności i napojów w 2018 r.” wynika, że wśród badanych konsumentów uwidaczniają się obawy odnośnie wiarygodności informacji na temat produktu i związanego z tym bezpieczeństwa żywności (Trendy..., 2017). Wymusza to konieczność rzetelnego prezentowania składu produktów, procesu ich wytwarzania czy też organizacji łańcucha dostaw, co pozwoli redukować niepokój konsumentów. Jak wynika z cytowanego Raportu, nieufność konsumentów względem zamieszczanych informacji na produktach żywnościowych, zauważalna jest na wszystkich badanych kontynentach (przykładowo zaledwie, co piaty dorosły Kanadyjczyk ufa umieszczanej na opakowaniach żywności informacji, iż produkt jest „zdrowy”, fakt ten niepokoi również ok. 45\% Chińczyków, podobne proporcje można także zauważyć wodniesieniu do krajów europejskich). Należy podkreślić, że konsumentów interesuje również miejsce wytworzenia produktu, preferując $\mathrm{w}$ tym względzie produkty żywnościowe rodzimego pochodzenia (70\% Włochów, 66\% Francuzów, 58\% Hiszpanów, 56\% Niemców i 55\% Polaków zwraca na ten fakt uwagę przy zakupie żywności) (Trendy..., 2017).

Wychodząc naprzeciw oczekiwaniom współczesnych konsumentów, bardzo dobrym sposobem wzmacniającym ich zaufanie stają się certyfikaty jakościowe przyznawane produktom przez instytucje cieszące się zaufaniem publicznym. Jedną z takich kategorii, stanowiących gwarant tradycyjnego pochodzenia żywności i jej wysokiej jakości są produkty tradycyjne. Certyfikat wpisany na listę Ministerstwa Rolnictwa i Rozwoju Wsi stanowi gwarancję bezpieczeństwa produktów spożywczych i ich dobrego smaku, natomiast system ochrony i promocji produktów regionalnych i tradycyjnych należy uznać za istotny czynnik wpływający na zrównoważony rozwój obszarów wiejskich.

Celem opracowania jest przedstawienie postrzegania regionalnych produktów tradycyjnych przez konsumentów na tle masowej oferty produktów żywnościowych, w kontekście zachodzących zmian w postawach i zachowaniach współczesnych konsumentów. Założony cel obliguje do odpowiedzi na pytanie, czy konsumenci przy zakupie żywności zwracają uwagę na certyfikaty jakości oraz czy są skłonni zapłacić wyższą cenę $\mathrm{w}$ zamian za gwarancję tradycyjnej metody wytworzenia produktów, pochodzących z surowców z lokalnego rynku.

\section{Dane i metody}

W artykule poza metodą krytycznej analizy zagranicznej i krajowej literatury przedmiotu, odnoszącej się do podjętej tematyki oraz prezentacją informacji pochodzących ze stron internetowych, zaprezentowano wyniki badań własnych przeprowadzonych metoda wywiadu kwestionariuszowego $\mathrm{w}$ drugim kwartale $2018 \mathrm{r}$. na próbie $\mathrm{n}=221$. Respondentami byli mieszkańcy woj. podkarpackiego, zastosowano dobór nielosowy kwotowy, z uwzględnieniem wieku (w przedziale 19-24 lata: 28\%, 25-35 lat: 30,6\%, 40-59 lat: 23,7\%, 60 lat i więcej: 12,9\%) oraz płci badanych (mężczyźni 48,2\%, kobiety: 51,8\%). Poza podstawowymi miernikami statystyki opisowej wykonano test Chi-kwadrat Pearsona, przy poziomie istotności $\alpha=0,05$. Przeprowadzano analiza pozwoliła określić, czy cechy 
respondentów (wiek i płeć) mają statystycznie istotny wpływ na postawy względem produktów tradycyjnych przy zakupie żywności

\section{Preferencje żywieniowe konsumentów w kontekście ogólnoświatowych tendencji - wybrane aspekty}

W zagranicznej i krajowej literaturze przedmiotu wskazuje się, że konsumenci XXI w. poddawani są presji otoczenia społeczno - kulturowego, ekonomicznego, politycznego czy technologicznego, efektem czego są ich zmiany postaw i zachowań. Wśród najbardziej charakterystycznych tendencji wskazuje się na: dekonsumpcję, świadomą konsumpcję, konsumpcję współpracująca, freeganizm, prosumpcję, smart shopping oraz domocentryzm (Zalega, 2013).

Wyznacznikiem zachodzących zmian może być zatem świadoma redukcja dotychczasowej konsumpcji, wynikająca z ograniczeń ilościowych na rzecz zwiększenia aspiracji jakościowych (Smyczek i Sowa 2005), oszczędne wykorzystanie dóbr konsumpcyjnych czy też większe użycie dóbr ekologicznych uzyskiwanych metodami naturalnymi i ograniczanie użycia takich dóbr, których produkcja związana jest z wykorzystaniem nieodnawialnych zasobów naturalnych, tworzeniem toksycznych odpadów (Zalega, 2013).

Jednym z wyzwań XXI w. jest zmiana nawyków żywieniowych konsumentów oraz walka z otyłością, marnowaniem żywności i nadmierną konsumpcją, które przyczyniają się do zwiększenia emisji gazów cieplarnianych i zmiany klimatu. Ważnym problemem wymuszającym zmiany w postawach i zachowaniach konsumentów są również rozwijające się choroby cywilizacyjne, w tym zwłaszcza choroby nowotworowe. Świadomość zagrożeń wynikających z niewłaściwego odżywiania sprawia, że konsumenci poszukują żywności prozdrowotnej (funkcjonalnej) i poszukuja wiarygodnych informacji na ten temat. Rozwojowi światowego rynku żywności prozdrowotnej sprzyja rozwój biotechnologii i badania nad modyfikowanymi organizmami, przyczyniające się do powstawania nowych odmian żywności funkcjonalnej (Korbutowicz, 2018). Największym na świecie rynkiem żywności prozdrowotnej jest Ameryka Północna, na drugim miejscu Europa, a na trzecim region Azji-Pacyfiku (m.in. Japonia, Australia, Nowa Zelandia, Rosja). W Europie w 2016 r. wartość rynku żywności funkcjonalnej osiagnęła wg KPMG 117 mld EUR, w Polsce zaś - 3,7 mld EUR (Rynek żywności...., 2017).

Wymienione, wybrane cechy produktu żywnościowego wpisują się w nowy trend konsumencki określany jako LOHAS (Lifestyles of Health and Sustainability) (Mróz, 2013), którego głównymi wyznacznikami są między innymi odejście od tzw. zachłannej konsumpcji (dekonsumpcja) oraz bezpieczne odżywianie się (ekokonsumpcja).

W związku ze wzrastającym uwrażliwieniem konsumentów na problem zdrowia, oczekują oni od producentów żywności przejrzystości i zgodnych z prawdą informacji na temat produktu. Współcześni konsumenci są zainteresowani nie tylko składem produktu żywnościowego czy metodą jego przetwarzania, ale także pochodzeniem składników używanych do wytworzenia żywności i napojów. Wyniki prowadzone pod kierunkiem N.J. Ollberdinga wskazuja, że ponad połowa konsumentów $(61,6 \%)$ zwraca uwagę na wartość odżywczą oraz na skład produktu $(51,6 \%)$, nieznacznie mniejsza grupa $(43,8 \%)$ na walory zdrowotne przy zakupie produktu żywnościowego (Ollberding, 2010). Producenci wychodzą naprzeciw oczekiwaniom klientów, gdyż jak podaje raport Mintel, między 
wrześniem 2016 r. a sierpniem 2017 r. 29\% wprowadzanych na rynek produktów zawierało informację, że oferowany produkt jest naturalny, czyli nie zawiera sztucznych składników, jest ekologiczny lub wolny od GMO. Dekadę wcześniej odsetek takich produktów wynosił jedynie 17\% (Trendy..., 2017).

Ze względu na uwrażliwienie konsumentów na problem zdrowia dynamicznie rozwija się również rynek żywności ekologicznej oraz tradycyjnej, uprawianej zgodnie $\mathrm{z}$ naturalnymi procesami biologicznymi, co zauważalne jest zwłaszcza w krajach wysoko rozwiniętych. Należy podkreślić, że aż $74 \%$ objętego certyfikacją ekologiczną areału znajduje się na terenie 10 krajów. Wśród państw europejskich sprzedaż żywności ekologicznej w 2016 r. osiagnęła wartość 31,1 bln dolarów (w czołówce pod względem znajdują się Niemcy i Francja). Uwzględniając wydatki na ekożywność per capita najwyższe pozycje zajmują: Szwajcaria (262 euro), Dania (191 euro) oraz Szwecja (177 euro) (Światowy rynek... 2017).

\section{Produkty tradycyjne jako oferta dla wymagających konsumentów}

Ważną pozycję w ofercie żywieniowej dla wymagających konsumentów stanowią produkty tradycyjne lokalnego pochodzenia. Przeglądu percepcji walorów żywności tradycyjnej wśród konsumentów z innych krajów dokonały m.in. M. GrzybowskaBrzezińska oraz J. Klepacka (2015). Odwołując się do wyników przeprowadzonych przez zagranicznych badaczy autorki wykazały, że europejscy konsumenci definiują tradycyjną żywność jako przekazywaną z pokolenia na pokolenie, wytwarzaną w specyficzny sposób, zgodnie z dziedzictwem kulinarnym, przetwarzaną w sposób naturalny, wyróżnianą i znaną ze względu na jej właściwości sensoryczne oraz związaną z pewnym obszarem lokalnym, regionem lub krajem (Guerrero i in. 2009: za Grzybowska-Brzezińska i Klepacka, 2015). Wśród czynników wyróżniających żywność tradycyjną Pieniak, Verbeke, Vanhonacker., Guerrero, Hersleth (2009: za Grzybowska-Brzezińska i Klepacka, 2015) wskazali przede wszystkim na naturalność, brak konserwantów, miejsce wytworzenia. W badaniach prowadzonych przez cytowanych autorów w poszczególnych krajach europejskich najwyższe oceny przyznaje się najczęściej atrybutom sensorycznym żywności tradycyjnej, a następnie wskazuje się na atrybuty zdrowia (zdrowotność, bezpieczeństwo, wartość odżywcza) oraz atrybuty etyczne identyfikowane jako przyjazne dla środowiska oraz wspierające lokalną gospodarkę.

Funkcjonujący w Europie system ochrony wyrobów wytwarzanych na określonym obszarze w sposób tradycyjny stanowi nie tylko gwarancję wysokich walorów żywnościowych, ale także dąży do ochrony nazw zarejestrowanych produktów i zapewnienia ich autentyczności. Do państw wiodących pod względem wartości produkcji objętej oznaczeniami geograficznymi należy zaliczyć Włochy, Niemcy, Francję i Wielką Brytanię.

W Polsce w licznych publikacjach poświęconych tematyce tradycyjnych produktów żywnościowych wskazuje się, że produkty te podkreślają tożsamość regionu, promując przy tym jego walory na zewnątrz. W ostatnich kilkunastu latach w skali wszystkich województw obserwowany jest dynamiczny wzrost w zakresie rejestracji produktów tradycyjnych. W 2006 roku zarejestrowanych było 499 produktów, w 2009 r. - 700 produktów, natomiast w 2018 r. - już 1814. W przeciagu ostatnich dwunastu lat nastąpił zatem ponad trzykrotny wzrost liczby zarejestrowanych produktów. Wiodące miejsce na liście zajmują trzy województwa: podkarpackie, małopolskie oraz lubelskie (tab. 1). 
Tabela 1. Liczba produktów tradycyjnych w Polsce w wg województw w ujęciu czasowym Table1. Number of traditional products in Poland, by voivodships in terms of time

\begin{tabular}{|c|c|c|c|c|c|c|}
\hline \multirow{2}{*}{ Województwo } & \multicolumn{2}{|c|}{2006} & \multicolumn{2}{|c|}{2018} & \multicolumn{2}{|c|}{ Wzrost w ciągu 12 lat } \\
\hline & $\mathrm{lb}$ & $\%$ & $\mathrm{lb}$ & $\%$ & $\mathrm{lb}$ & $\%$ \\
\hline Dolnośląskie & 12 & 2,4 & 49 & 2,7 & 37 & 308,3 \\
\hline Kujawsko-pomorskie & 14 & 2,8 & 81 & 4,5 & 67 & 478,6 \\
\hline Lubelskie & 41 & 8,2 & 203 & 11,2 & 162 & 395,1 \\
\hline Lubuskie & 6 & 1,2 & 69 & 3,8 & 63 & 1050,0 \\
\hline Łódzkie & 19 & 3,8 & 135 & 7,4 & 116 & 610,5 \\
\hline Małopolskie & 26 & 5,2 & 208 & 11,5 & 182 & 700,0 \\
\hline Mazowieckie & 9 & 1,8 & 128 & 7,1 & 119 & 1322,2 \\
\hline Opolskie & 43 & 8,7 & 62 & 3,4 & 19 & 44,2 \\
\hline Podkarpackie & 64 & 12,8 & 226 & 12,5 & 162 & 253,1 \\
\hline Podlaskie & 35 & 7,0 & 66 & 3,6 & 31 & 88,6 \\
\hline Pomorskie & 75 & 15,0 & 178 & 9,8 & 103 & 137,3 \\
\hline Śląskie & 77 & 15,4 & 145 & 8,0 & 68 & 88,3 \\
\hline Świętokrzyskie & 17 & 3,4 & 92 & 5,1 & 75 & 441,2 \\
\hline Warmińsko-mazurskie & 11 & 2,2 & 31 & 1,7 & 20 & 181,8 \\
\hline Wielkopolskie & 45 & 9,1 & 93 & 5,1 & 48 & 106,7 \\
\hline Zachodniopomorskie & 5 & 1,0 & 48 & 2,6 & 43 & 860,0 \\
\hline RAZEM & 499 & 100,0 & 1814 & 100,0 & 1315 & Średnia 441,6 \\
\hline
\end{tabular}

Źródło: opracowanie własne na podstawie danych z Ministerstwa Rolnictwa i Rozwoju Wsi.

Aktywność w zakresie rozwoju produktów tradycyjnych lokalnego pochodzenia jest coraz bardziej zauważana w województwie podkarpackim. Region ten posiada bardzo bogate dziedzictwo kulinarne. W ostatnich latach zauważa się odkrywanie na nowo zapomnianych smaków, a także intensywne działania mające na celu promowanie regionalnej sztuki kulinarnej. Według stanu na czerwiec 2018, Podkarpacie zajmuje pozycję lidera pod względem liczby zarejestrowanych produktów. Bogata oferta kulinarna wynika także $\mathrm{z}$ faktu, że w województwie podkarpackim tradycje polskie mieszają się ze zwyczajami sąsiadów zza wschodniej i południowej granicy regionu, co dodatkowo wpływa na unikalność oferowanych produktów.

\section{Postawy konsumentów woj. podkarpackiego wobec produktów tradycyjnych w świetle wyników badań ankietowych}

Województwo podkarpackie jako lider listy produktów tradycyjnych w Polsce stwarza klientom z regionu możliwość dużego wyboru żywności opatrzonej certyfikatem produktu tradycyjnego z Podkarpacia. Towary te są dostępne zarówno na półkach małych sklepów spożywczych, obiektów wielkopowierzchniowych, jak również istnieje możliwość ich nabycia w sprzedaży bezpośredniej. Konsumenci mają zatem bogaty wybór towarów spośród ofert dań gotowych, produktów mięsnych, piekarniczo-cukierniczych, mlecznych czy też miodów i napojów. Część produktów tradycyjnych jest wykorzystywana w licznych 
gospodarstwach agroturystycznych i ekoagroturystycznych funkcjonujących na Podkarpaciu, stanowiąc dużą atrakcję kulinarną, oferowaną przyjeżdżającym na wieś gościom (Kuźniar i Witek, 2016). Oryginalny, niepowtarzalny smak oraz walory zdrowotne podkarpackich produktów tradycyjnych znajdują potwierdzenie w wysokich ocenach przyznawanych przez konsumentów ${ }^{3}$. Satysfakcję z ich nabywania potwierdzają wyniki wielu badań wskazujące, że konsumenci poza wysokimi walorami smakowymi i zdrowotnymi, cenią sobie również regionalne pochodzenie produktów oraz powiązanie z lokalną kulturą (Grzybek i Szopiński, 2017).

Znaczenie certyfikatu produktu tradycyjnego $\mathrm{w}$ procesie zakupowym badanych konsumentów Podkarpacia przedstawia tabela 2.

Tabela 2. Znaczenie certyfikatu produktu tradycyjnego w procesie zakupowym klientów (w \%)

Table 2. The importance of traditional product certificates in custome' purchasing process (in \%)

\begin{tabular}{l|rrrrrrr}
\hline \multirow{2}{*}{ Wyszczególnienie } & Ogółem & \multicolumn{3}{c}{ Wiek } & & \multicolumn{2}{c}{ Płeć } \\
& & $19-24$ & $25-39$ & $40-59$ & 60 i więcej & Mężcz. & Kobiety \\
\hline Zdecydowanie tak & 20,9 & 6,2 & 18,3 & 23,6 & 26,7 & 11,7 & 20,9 \\
Raczej tak & 64.3 & 66,2 & 62,0 & 60,0 & 73,3 & 65,0 & 64,3 \\
Raczej nie & 13,0 & 24,5 & 16,9 & 16,4 & 0 & 21,4 & 13,0 \\
Zdecydowanie nie & 1,8 & 3,1 & 2,8 & 0 & 0 & 1,9 & 1,8 \\
\hline
\end{tabular}

Źródło: obliczenia własne na podstawie przeprowadzonego badania ankietowego.

W celu określenia, czy cechy respondentów mają statystycznie istotny wpływ na postawy względem produktów tradycyjnych przy zakupie żywności wykonano test Chi-kwadrat Pearsona, przy poziomie istotności $\alpha=0,05$. Analizując wpływ wieku zauważa się, że im starsi konsumenci tym zwiększa się odsetek zdecydowanych deklaracji odnośnie preferowania produktów tradycyjnych w procesie zakupowym konsumentów. Zależność ta okazała się statystycznie istotna $\left(\mathrm{p}=0,0302, \chi^{2}=18,4555\right)$. Należy podkreślić, że tylko dla nielicznych konsumentów posiadanie certyfikatu produktu tradycyjnego nie ma żadnego znaczenia. Grupę tę najczęściej reprezentują mężczyźni w wieku 19-24 lata. Fakt nabywania regionalnego produktu tradycyjnego dla kobiet ma większe znaczenie $(85,2 \%$, w tym $20,9 \%$ zdecydowanie) aniżeli dla mężczyzn $(76,7 \%$, w tym tylko $11,7 \%$ zdecydowanie). Płeć respondentów nie wpływała jednak statystycznie istotnie na znaczenie dla konsumenta faktu posiadania przez zakupywaną żywność certyfikatu produktu tradycyjnego $\left(p=0,1698, \chi^{2}=5,0265\right)$.

Konsekwencją preferowania przez konsumentów produktów posiadających certyfikat jakościowy jest ich gotowość do zapłacenia wyższej ceny w zamian za gwarantowaną jakość i smak produktu (tab. 3).

\footnotetext{
${ }^{3}$ Kuźniar W., Witek L. (2016). Traditional Regional Products As Part of Unique Sales Proposition in Farm Tourism in Poland. Scientific Papers Series Management, Economic Engineering in Agriculture and Rural Development, 16(1), 249-252.

${ }^{4}$ Grzybek M. Szopiński (2017) W. Zachowania konsumentów na rynku produktów regionalnych i tradycyjnych Zeszyty Naukowe Szkoły Głównej Gospodarstwa Wiejskiego w Warszawie. Problemy Rolnictwa Światowego 17(1), 43-52.
} 
Tabela 3. Deklarowana gotowość do zapłaty wyższej kwoty za produkty tradycyjne (w \%)

Table 3. Declared willingness to pay a higher amount of money for products (in \%)

\begin{tabular}{l|rrrrrrr}
\hline \multirow{2}{*}{ Wyszczególnienie } & \multirow{2}{*}{ Ogółem } & \multicolumn{3}{c}{ Wiek } & \multicolumn{2}{c}{ Płeć } \\
& & $19-24$ & $25-39$ & $40-59$ & 60 i więcej & Mężcz. & Kobiety \\
\hline Zdecydowanie tak & 13,6 & 3,1 & 15,5 & 23,6 & 13,3 & 13,6 & 13,9 \\
Raczej tak & 57,5 & 49,2 & 53,5 & 56,4 & 86,7 & 47,6 & 65,2 \\
Wielkość deklarowanej dopłaty w stosunku do zwykłego produktu: & & & \\
Do 10\% & 28,5 & 26,4 & 22,5 & 18,2 & 50,0 & 19,4 & 30,4 \\
Do 25\% & 38,9 & 18,5 & 36,6 & 60,0 & 50,0 & 33,0 & 44,3 \\
Do 50\% & 3,6 & 7,7 & 2,8 & 1,8 & - & 3,9 & 3,5 \\
Powyżej 50\% & 2,3 & - & 7,0 & - & - & 4,3 & - \\
\hline
\end{tabular}

Źródło: obliczenia własne na podstawie przeprowadzonego badania ankietowego.

Zdecydowanie w kwestii możliwości dopłaty wyraził średnio co ósmy konsument, natomiast ponad połowa $(57,5 \%)$ deklaruje ewentualną gotowość do zakupu żywności tradycyjnej w wyższej cenie. Wraz $\mathrm{z}$ wiekiem konsumentów zauważa się większą skłonność do dopłacenia wyższej kwoty za produkt tradycyjny. Zależność ta jest okazała się statystycznie istotna $(\mathrm{p}=0,0446, \chi 2=8,0718)$. Płeć nie różnicowała $\mathrm{w}$ sposób statystycznie istotny składanych deklaracji $(\mathrm{p}=0,4546, \chi 2=0,5591)$. Najwyższy odsetek badanych $(38,9 \%)$ jest skłonny dopłacić do tradycyjnej ceny maksymalnie do $25 \%$, nieco mniejsza grupa $(28,5 \%)$ deklaruje gotowość dopłaty jedynie do $10 \%$, w stosunku do porównywalnych produktów bez certyfikatu. Nieco bardziej zdecydowane w tym względzie okazały się kobiety, w stosunku do mężczyzn.

Mimo, że przeważająca część konsumentów preferuje produkty tradycyjne, to jednak w nieco mniejszym stopniu wykazują skłonność do poszukiwania produktów rodzimego pochodzenia (tab. 4).

Tabela 4. Preferowanie przy zakupie produktów tradycyjnych pochodzenia z regionu Podkarpacia (w \%)

Table 4. Preference when buying traditional products from the Podkarpacie region (in \%)

\begin{tabular}{l|rrrrrrr}
\hline \multirow{2}{*}{ Wyszczególnienie } & Ogółem & \multicolumn{3}{c}{ Wiek } & \multicolumn{2}{c}{ Płeć } \\
& & $19-24$ & $25-39$ & $40-59$ & 60 i więcej & Mężcz. & Kobiety \\
\hline Zdecydowanie tak & 24,9 & 12,3 & 26,8 & 16,4 & 63,3 & 33,0 & 17,4 \\
Raczej tak & 39,8 & 35,4 & 31,0 & 58,2 & 36,7 & 26,2 & 51,3 \\
Raczej nie & 35,3 & 52,3 & 42,2 & 25,4 & - & 40,8 & 31,3 \\
Zdecydowanie nie & - & - & - & - & - & - & - \\
\hline
\end{tabular}

Źródło: obliczenia własne na podstawie przeprowadzonego badania ankietowego.

Z badań wynika, że zaledwie co czwarty badany zdecydowanie zadeklarował w procesie zakupowym swoją lojalność względem produktów tradycyjnych pochodzących z Podkarpacia, blisko połowa stara się to czynić, jednak nie zawsze uwzględnia regionalne preferencje w tym zakresie. Na podstawie uzyskanych wyników można stwierdzić, że wiek $\left(\mathrm{p}=0,00037, \chi^{2}=30,4606\right)$ istotnie wpływał na deklarowane postawy $\mathrm{w}$ zakresie preferowania produktów tradycyjnych z regionu. Najsłabiej postawy te były wykształcone w grupie konsumentów najmłodszych, reprezentujących przedział wiekowy 19-24 lata, im 
starsi konsumenci tym występowało silniejsze przywiązanie do produktów tradycyjnych pochodzących $\mathrm{z}$ regionu. Płeć jako zmienna nie wpływała w sposób istotny na postawy zakupowe względem produktów tradycyjnych pochodzących $\mathrm{z}$ regionu Podkarpacia $\left(\mathrm{p}=0,0565, \chi^{2}=5,9746\right)$. Należy podkreślić, że $\mathrm{z}$ innych badań prowadzonych wśród konsumentów woj. podkarpackiego wynika, iż najwięcej uwagi w zakresie wyboru określonych cech jakościowych produktu tradycyjnego poświęca się przy zakupie wędlin i mięsa $(93,4 \%)$, wyrobów mlecznych $(64,7 \%)$ oraz pieczywa $(55,1)$. Zaangażowanie konsumentów w tym zakresie nasila się wraz ze wzrostem ich wykształcenia. (Kuźniar, Kawa, Kuźniar, 2016).

\section{Podsumowanie}

Z licznych badań prowadzonych zarówno w skali globalnej, jak również na poziomie krajowym wynika, że współcześni konsumenci to osoby coraz bardziej niezależne, wyedukowane i świadome zagrożeń płynących ze spożywania produktów o niskiej jakości. Zakupując żywność zwracają uwagę nie tylko na jej skład czy termin przydatności produktu, ale także oczekuja, aby była ona wytwarzana za pomocą bezpiecznych metod przetwarzania czy utrwalania. Konsumenci XXI wieku oczekują zatem, aby nabywane przez nich produkty żywnościowe były nie tylko smaczne, lecz przede wszystkim bezpieczne dla zdrowia. Coraz większym atutem staje się również lokalne pochodzenie żywności, nawiązującej od tradycyjnych smaków.

Produkty tradycyjne wychodzą naprzeciw wzrastającym oczekiwaniom klientów na rynku żywności, stanowiąc atrakcyjną alternatywę dla produktów masowych. Ich dynamiczny rozwój od końca XX w. wpisuje się w ogólnoświatowe tendencje obserwowane w sferze konsumpcji, których wyznacznikiem jest odejście od tzw. zachłannej konsumpcji, ekologiczne odżywianie się, promowanie zdrowego stylu życia, zrównoważony rozwój, czy też poszanowanie środowiska.

W kontekście postępujących chorób cywilizacyjnych, ważnym wyznacznikiem jakości produktów żywnościowych stają się zatem funkcje prozdrowotne, co stanowi istotny argument przy zakupie, zwłaszcza wśród osób starszych, borykających się z licznymi problemami zdrowotnymi. Tendencje te zauważalne są wśród badanych respondentów woj. podkarpackiego. Konsumenci ci, pomimo często niskich dochodów są skłonni dopłacić za produkty spożywcze, posiadające certyfikat produktu tradycyjnego czy też ekologicznego, będący gwarantem wysokiej jakości nabywanej żywności.

Na podstawie przeprowadzonych badań można stwierdzić, że

1. Im starsi konsumenci, tym deklarowana jest większa gotowość do zapłaty wyższej ceny w zamian na tradycyjne pochodzenie produktów.

2. Wraz z wiekiem konsumentów zwiększa się zainteresowanie produktami tradycyjnymi pochodzącymi z Podkarpacia,

3. Fakt nabywania regionalnego produktu tradycyjnego ma nieco większe znaczenie dla kobiet aniżeli mężczyzn.

Powodem, dla którego konsumenci sięgają po regionalne produkty tradycyjne jest także chęć wspierania lokalnego rolnictwa. Preferując przy zakupie produkty pochodzące z regionu identyfikują się ze swoimi „,małymi ojczyznami”, wspierając tym samym rozwój gospodarki regionalnej i lokalnej. W przyszłych badaniach, autorki zamierzają rozszerzyć 
zakres przestrzenny i przedmiotowy oraz dokonać pogłębionej analizy postaw i zachowań z uwzględnieniem wykształcenia konsumentów.

\section{Literatura}

Grzybek, M. Szopiński, W. (2017). Zachowania konsumentów na rynku produktów regionalnych i tradycyjnych. (Consumer Behaviour on the Market of Regional and Traditional Products). Zeszyty Naukowe Szkoty Głównej Gospodarstwa Wiejskiego w Warszawie. Problemy Rolnictwa Światowego, 17(1), 43-52.

Grzybowska-Brzezińska, M., Klepacka, J. (2015). Percepcja atrybutów produktu żywności tradycyjnej (Perception of Attributes of the Traditional Food Product). Handel Wewnętrzny 3(356), 80-89.

Guerrero, L., Guardia, M.D., Xicola, J., Verbeke, W., Vanhonacker, F., Żakowska-Biemans, S., Vanhonacker, F. (2009). Consumer-driven Definition of Traditional Food Products and Innovation in Traditional Foods. A Qualitative Cross-cultural Study, Appetite, 52(2), 345-354.

Korbutowicz, T. (2018). Żywność funkcjonalna na rynku światowym (Functional Foods on the World Market, Studia i Prace WNEIZ US 53/2, 209-220.

Kuźniar, W., Witek, L. (2016). Traditional Regional Products As Part of Unique Sales Proposition in Farm Tourism in Poland. Scientific Papers Series Management, Economic Engineering in Agriculture and Rural Development 16(1), 249-252.

Kuźniar, W., Kawa, M., Kuźniar, P. (2016). Konsumenci wobec bezpiecznych rozwiazań w zakresie produkcji żywności (Consumer Attitudes Towards Safe Solutions for Food Productions). Zeszyty Naukowe Szkoły Głównej Gospodarstwa Wiejskiego w Warszawie. Problemy Rolnictwa Światowego, 16(3), 243-250.

Mróz, B. (2013). Konsument w globalnej gospodarce. Trzy perspektywy (Consumer in the Global Economy: Three Perspectives). Warszawa: Oficyna Wydawnicza Szkoła Główna Handlowa w Warszawie, 136-137.

Ollberding, N.J. Wilk, R.L., Contento, I. (2010). Food Label Use and its relation to dietary intake among US adults. Journal of the American Dietetic Association 110(8), 1233-1237.

Pieniak, Z., Verbeke, W., Vanhonacker, F., Guerrero, L., Hersleth, M. (2009). Association between traditional food consumption and motives for food choice in six European countries. Appetite 53(1), 101-108.

Rynek żywności funkcjonalnej w Polsce wart 3,7 mld euro (Functional Food Market in Poland is worth 3.7 billion EUR). Portalspożywczy.pl. Pobrano 1 czerwca 2018 z: http://www.portalspozywczy.pl/handel/artykuly/ rynek-zywnosci-funkcjonalnej-w-polsce-wart-3-7-mld-euro,150905.html.

Smyczek, S., Sowa, I. (2005). Konsument na rynku. Zachowania, modele, aplikacje (Consumer on the Market. Behaviors, Models, Applications). Wyd. Difin, Warszawa.

Światowy rynek żywności ekologicznej przekroczył wartość 80 bln dolarów i rośnie w tempie 10\% (The Global Market for Organic Food has Exceeded 80 bilion USD and is Growing at a Rate of 10\%) Pobrano 1 czerwca 2018 z: http://biokurier.pl/ekorynek/swiatowy-rynek-zywnosci-ekologicznej-przekroczyl-wartosc-80-blndolarow-i-rosnie-w-tempie-10/.

Trendy na globalnym rynku żywności i napojów w 2018 r. (Global Food and Drink Trends 2018). Raport Mitel, 2017.

Zalega, T. (2013). Nowe trendy i makrotrendy w zachowaniach konsumenckich gospodarstw domowych w XXI wieku (New Trends and Megatrends in the Households' Consumption Behaviour in the 21st Century). Konsumpcja i Rozwój 2(5), 3-21.

Do cytowania / For citation:

Kuźniar W., Kawa M. (2018). Konsumenci wobec regionalnych produktów tradycyjnych w kontekście ogólnoświatowych zmian w zachowaniach konsumentów na rynku żywności. Problemy Rolnictwa Światowego, 18(4), 307-312; DOI: 10.22630/PRS.2018.18.4.120

Kuźniar W., Kawa M. (2018). Consumers' Attitudes Towards Regional Traditional Products in the Context of Global Changes in Consumer Behaviour on Food Market (in Polish). Problems of World Agriculture, 18(4), 307-312; DOI: 10.22630/PRS.2018.18.4.120 